\title{
Age and growth parameters of cachara Pseudoplastystoma reticulatum (Siluriformes, Pimelodidae) from the Cuiabá River, Brazil
}

\author{
Talitha M. Francisco ${ }^{1}$, Angela Maria Ambrósio ${ }^{1}$, Thiago José Balbi ${ }^{1}$, Marina S. Zuliani ${ }^{1}$, \\ Edson K. Okada ${ }^{1} \&$ Luiz C. Gomes ${ }^{1,2}$
}

1. Núcleo de Pesquisas em Limnologia, Ictiologia e Aquicultura - Nupélia, Universidade Estadual de Maringá, Av. Colombo, 5790, 87020-900, Maringá, Paraná, Brazil. (talithamayumi@hotmail.com)
2. Curso de Pós-Graduação em Ecologia de Ambientes Aquáticos Continentais, Departamento de Biologia, Universidade Estadual de Maringá, Av. Colombo, 5790, 87020-900, Maringá, Paraná, Brazil.

\begin{abstract}
Age and growth parameters of cachara Pseudoplatystoma reticulatum (Eigenmann \& Eigenmann, 1889) (Siluriformes, Pimelodidae) (males and females) were estimated through the analysis of growth rings in spines of pectoral fins. Fish were collected from January to December 2007, in the area directly influenced by the Aproveitamento Múltiplo de Manso (APM Manso) and in the Cuiabá River (upper parts of the Pantanal). The maximum number of growth rings was seven for males, and eight, for females. The analysis of temporal variations in mean marginal increment showed that rings found in the spines were formed annually, in December. Growth rings were associated to spawning (in the study region from November to March) of the species. The growth curve in length was obtained by the von Bertalanffy model adjusted by the Ford-Walford transformation. The equations are: $\mathrm{Ls}=72.7 *\left[1-\mathrm{e}^{-0.44(t+1.5974)}\right]$ for males, and Ls $=84.5 *\left[1-\mathrm{e}^{-0.33(t+2.0943)}\right]$ for females. The equations that describe the growth curve in weight are: $\mathrm{Wt}=4991.61 *\left[1-\mathrm{e}^{-0.44(t+1.5974}\right]^{2.70}$ for males and $\mathrm{Wt}=7503.17 *\left[1-\mathrm{e}^{-0.33(t+2.0943}\right]^{2.99}$ for females.
\end{abstract}

KEYWORDS. Growth rings, pectoral fins, von Bertalanffy model, Ford-Walford.

RESUMO. Idade e parâmetros de crescimento do cachara Pseudoplastystoma reticulatum (Siluriformes, Pimelodidae) do rio Cuiabá, Brasil. A idade e os parâmetros de crescimento de machos e fêmeas do cachara, Pseudoplastystoma reticulatum (Eigenmann \& Eigenmann, 1889) (Siluriformes, Pimelodidae), coletados de janeiro a dezembro de 2007, na área de influencia do Aproveitamento Múltiplo de Manso (APM Manso) e rio Cuiabá (parte superior do pantanal), foram estimados através das marcas de aposição (anéis) observadas nos acúleos das nadadeiras peitorais. O número máximo de anéis encontrados foi sete para os machos e oito para as fêmeas. Os anéis encontrados nos acúleos foram anuais e formados em dezembro, como observado através da análise da variação temporal do incremento marginal médio. Possivelmente estes estão relacionados com a época de reprodução para a espécie na área (novembro a março). A curva de crescimento em comprimento foi obtida pelo modelo de von Bertalanffy, ajustada pela transformação Ford-Walford. As equações são: $\mathrm{Cp}=72,7 *\left[1-\mathrm{e}^{-0,44(t+1,5974)}\right]$ para machos e Cp $=84,5 *\left[1-\mathrm{e}^{-0,33(t(t 2,0943)}\right]$ para fêmeas. As equações que descrevem a curva de crescimento em peso são: $\mathrm{Pt}=4991,61 *\left[1-\mathrm{e}^{-0,44(t+1,5974)}\right]^{2,70}$ para machos $\mathrm{e} \mathrm{Pt}=7503,17 *\left[1-\mathrm{e}^{-0,33(+2,0943)}\right]^{2,99}$ para fêmeas.

PALAVRAS-CHAVE. Marcas de aposição, nadadeira peitoral, modelo de von Bertalanffy, Ford-Walford.

Studies on population dynamics are essential to improve knowledge on the biology of fish species (NIKOLSKY, 1969). Therefore, the determination of age from calcified structures of fish is a vital component of most present-day fisheries management decisions (CAMPANA, 2001), despite the difficulties to study growth, particularly in tropical regions (MENON, 1953; FERREIRA \& RUSS 1994), where fish diversity is high.

This high number of species, including in the Neotropical region, allows fisheries to be conducted on several species, especially Characiformes and Siluriformes (Petrere \& Agostinho, 1993; Mateus et al., 2004). These authors also showed that among the seven species of large Siluriformes (total length $>50$ $\mathrm{cm}$ ) of the Pantanal, four of them - Pseudoplatystoma corruscans (Spix \& Agassiz, 1829), Pseudoplastystoma reticulatum (Eigenmann \& Eigenmann, 1889), Pinirampus pirinampu (Agassiz, 1829) and Zungaro $j a h u$ (Ihering, 1898) - represented $64 \%$ of the total catch in the Cuiabá city in 2000 and 2001. AlbuQUERQUe et al. (2003) and Silva (1986) also reported a great capture of $P$. reticulatum and $P$. corruscans in the same region. The great economic importance of $P$. reticulatum in the area studied is also discussed by RESENDE et al. (1996) and TAVARES (1997).

Pseudoplastystoma reticulatum is known in the region as cachara, surubim and surubim-cachara, with nocturnal habits and considered a piscivorous species (Resende et al., 1996). Taking into account the importance of $P$. reticulatum as a fishery resource in the area (Oliveira et al., 2005), this paper aims to determine the age and growth parameters of this species, a fundamental information for stock assessment. In addition, the periodicity in ring formation (monthly means of marginal increment) was analyzed and in order to validate it, we used the coefficient of variation of mean standard length for each age class. Thus, the von Bertalanffy model was adjusted to estimate the growth parameters for each sex. Finally, the results are discussed in relation to the biology of the species and some inferences are made on the effect of the fishery on the age structure of cachara.

\section{MATERIAL AND METHODS}

The Cuiabá River basin is located in the 'Cuiabana' depression, plains and 'pantanais' in the state of Mato Grosso. In the upper part of the studied area, is situated the APM Manso Reservoir (parallels $14^{\circ} 32^{\prime}$ $15^{\circ} 40^{\prime} \mathrm{S}$ and $54^{\circ} 40^{\prime}-55^{\circ} 55^{\prime} \mathrm{W}$ ) (Fig. 1). This was filled in 1999 and flooded a stretch of the Manso River and the lower sections of Casca, Palmeiras and Quilombo rivers. Downstream of the APM Manso Reservoir, the Manso River joins the Cuiabazinho River, forming the 


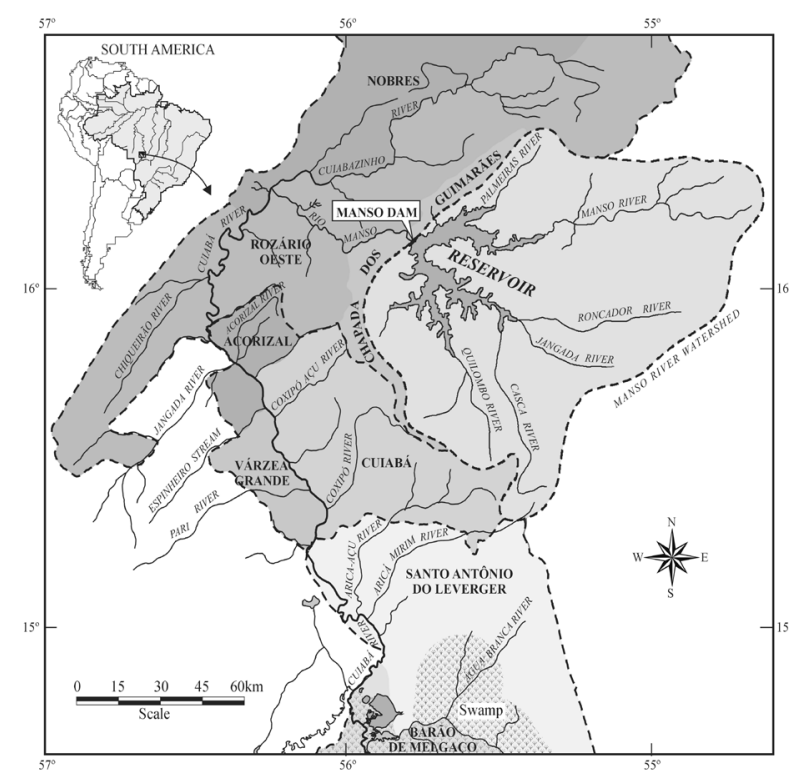

Fig. 1. Map of the fishery areas considered in the studied region (from Manso Reservoir to the upper part of the Pantanal, Brazil).

Cuiabá River. The Cuiabá River is the main tributary of the Paraguay River and forms the upper part of the 'Pantanal matogrossense' near the cities of Cuiabá and Várzea Grande (Oliveira et al., 2005).

Individuals of $P$. reticulatum were obtained monthly from January to December 2007 from the landings of the artisanal (professional) fisheries conducted in the region. In this region, gill nets are forbidden for fishing. Then, fishers employ several gears with hooks, such as long lines, rods, and line and hooks attached to branches (attached to trees in the margins). Every individual was measured (standard length, Ls; cm) and weighed (total weight, Wt; g). Sex was identified and the spines of the pectoral fins were removed. After removal, spines were cleaned, dried, cut and mounted between glass slides for reading, following REINA et al. (1995).

Identification of rings (annuli) in the spines was conducted under stereoscopic microscope, using a micrometer ocular. For each spine we measured the radius $(\mathrm{mm})$, which is the distance between the center of the spine (focus or nucleus) and its anterior margin, and the distance from the center of the spine to each annulus $(\mathrm{mm})$. We conducted three independent readings of all spines, and in case of discordance in the number of growth rings between readings, the spine was discarded or replaced.

To determine the timing and periodicity of ring formation, we calculated monthly means of the marginal increment, using the expression presented in LAI et al. (1996): M.I. $=\left(\mathrm{R}-\mathrm{r}_{\mathrm{i}}\right) /\left(\mathrm{r}_{\mathrm{i}}-\mathrm{r}_{\mathrm{i}-1}\right)$, where $\mathrm{R}=$ centrum-radii, the distance between the center of the spine (focus or nucleus) and its anterior margin; $r_{i}=$ ultimate annulusradii (the distance between the center of the spine and the ultimate annulus); and $r_{i-1}=$ penultimate annuli-radii (the distance between the center of the spine and the penultimate annulus).
Validation of the growth rings found in spines was performed through the analysis of the coefficient of variations $(\mathrm{CVs})$ for the standard mean lengths for each growth ring (LAI et al., 1996), for each sex separately.

The model selected to express the growth of $P$. reticulatum was the von Bertalanffy, adjusted using Ford-Walford transformation (WALFORD, 1946). This transformation was selected because a nonlinear procedure may result in incorrect growth parameters (unreal or inconsistent). After estimating the parameters $\mathrm{k}$ (growth rate) and $\mathrm{Ls}_{\infty}$ (asymptotic length), it was possible to determine the growth curve in length, described by the expression: $\mathrm{Ls}=\operatorname{Ls}_{\infty^{*}}\left[1-\mathrm{e}^{-\mathrm{k}(\mathrm{t}-\mathrm{t} 0)}\right]$, where $\mathrm{Ls}=$ standard length of the individuals with age " $\mathrm{t}$ " (cm); $\mathrm{Ls}_{\infty}=$ maximum standard (asymptotic) length that individuals can achieve $(\mathrm{cm})$; e = Napierian logarithm; $\mathrm{k}=$ parameter related to growth rate $\left(\right.$ year $\left.^{-1}\right) ; \mathrm{t}=$ age of individuals (years) and $t_{0}=$ age at which the organism would have had size equal zero. The parameter $t_{0}$ was estimated using the expression presented in VAzZOLER (1981). We also obtained the standard length vs. total weight relationship for each sex separately, using the nonlinear estimation and Levenberg-Marquardt method. The expression (LE CREN, 1951) used was: $\mathrm{Wt}=\mathrm{a}^{*} \mathrm{Ls}^{\mathrm{b}}$, where $\mathrm{Wt}=$ total weight $(\mathrm{g}) ; \mathrm{Ls}=$ standard length $(\mathrm{cm})$; $\mathrm{a}=$ intercept and $\mathrm{b}=$ slope.

After estimated the parameters of the length $\mathrm{x}$ weight relationship, we can determine the asymptotic weight $\left(\mathrm{Wt}_{\infty}\right)$, solving this relation for $\mathrm{Ls}_{\infty}$. This allows determining the growth in weight using the direct method as in AmBrósio et al. (2003), described by the expression: $\mathrm{Wt}=\mathrm{Wt}_{\infty} *\left[1-\mathrm{e}^{-\mathrm{k}(\mathrm{t}-\mathrm{t} 0)}\right]^{\mathrm{b}}$, where $\mathrm{Wt}=$ weight of individuals with age " $\mathrm{t}$ " $(\mathrm{g}) ; \mathrm{Wt}_{\infty}=$ maximum total (asymptotic) weight that individuals can achieve (g); e $=$ Napierian logarithm; $\mathrm{k}=$ parameter related to growth rate $\left(\right.$ year $\left.^{-1}\right) ; \mathrm{t}=$ age of individuals (years) $\mathrm{t}_{0}=$ age at which the organism would have had size equal zero, and $b=$ slope of the relationship between total weight and standard length. Since females may present larger body size (WootTon, 1998), models were fit for each sex separately.

\section{RESULTS}

In this study, 250 individuals of $P$. reticulatum (146 males and 104 females) were examined. For males, the smallest individual had $40.5 \mathrm{~cm}$ long and the largest had $85.0 \mathrm{~cm}$. The smallest female had $46.0 \mathrm{~cm}$ long, and the largest, $96.0 \mathrm{~cm}$. The number of rings varied from one to seven for males, and from one to eight for females; but most fish (of both sexes) presented three to five growth rings, showing that the population in the region presents few old individuals. The formation of the ring occurred in December when the mean monthly marginal increment was lower (Fig. 2).

The method selected to validate the rings observed in the spines of $P$. reticulatum was the coefficient of 
variation $(\mathrm{CV})$ of the standard length of all fish with the same number of rings, separated by sex (Tab. I). Overall, for this study, CV were low (below 20\%), indicating a good consistence in the readings.

The equations that describe the growth in length for the species are: $\mathrm{Ls}=72.7 *\left[1-\mathrm{e}^{-0.44(\mathrm{t}+1.5974)}\right]$ (males) and $\mathrm{Ls}=82.5^{*}\left[1-\mathrm{e}^{-0.33(\mathrm{t}+2.9043)}\right]$ (females). Females presented higher asymptotic length $\left(\mathrm{L}_{\infty}=82.5 \mathrm{~cm}\right)$ than males $\left(\mathrm{L}_{\infty}\right.$ $=72.7 \mathrm{~cm})$. The constant of growth was greater for the males $(\mathrm{k}=0.44)$ than for females $(\mathrm{k}=0.33)$, indicating that males grow faster (Fig. 3).

The relationship between standard length and total weight, for each sex (Fig. 4), was expressed by the following equations: $\mathrm{Wt}=0.047 * \mathrm{Ls}^{2.70}\left(\mathrm{R}^{2}=0.89\right)$ (males) and $\mathrm{Wt}=0.013 * \mathrm{Ls}^{2.99}\left(\mathrm{R}^{2}=0.91\right)$ (females). The confidence intervals to the constants $a$ and $b$ were, respectively: 0.012-0.082 and 2.52-2.87 (95\% level of confidence) for males and 0.0007-0.025 and 2.783.21 for females (95\% level of confidence). Thus, the equations that describe the growth in weight are: $\mathrm{Wt}$ $=4991.61 *\left[1-\mathrm{e}^{-0.44 *(\mathrm{t}+1.5974)}\right]^{2.70}$ for males; and $\mathrm{Wt}=$ $7503.17 *\left[1-\mathrm{e}^{-0.33^{*}(t+2.0943)}\right]^{2.99}$ for females.

\section{DISCUSSION}

Validation of rings in studies of age and growth is important and necessary to obtain unbiased parameters for the von Bertalanffy equation (CASSELMAN, 1983;

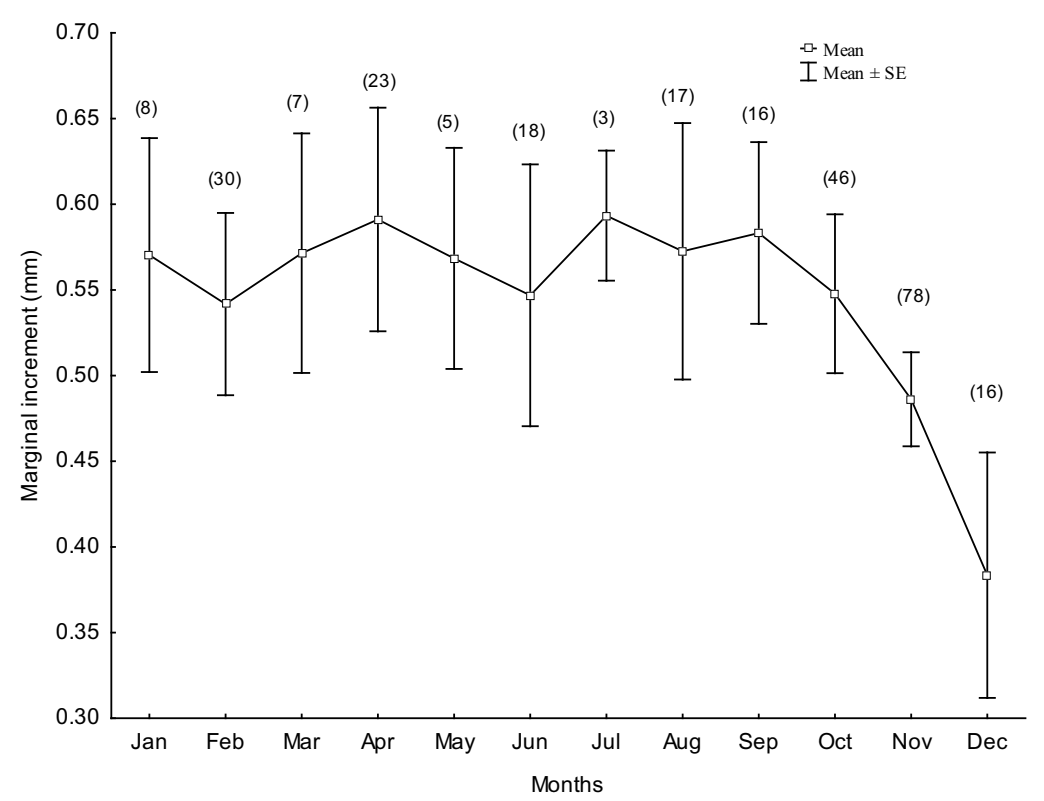

Fig. 2. Monthly averages \pm standard error (SE) of the marginal increments observed in spines of Pseudoplatystoma reticulatum (Eigenmann \& Eigenmann, 1889) collected between January and December of 2007 in APM Manso Reservoir and Cuiabá River, state of Mato Grosso, Brazil (numbers in brackets refer the number of individuals analyzed).

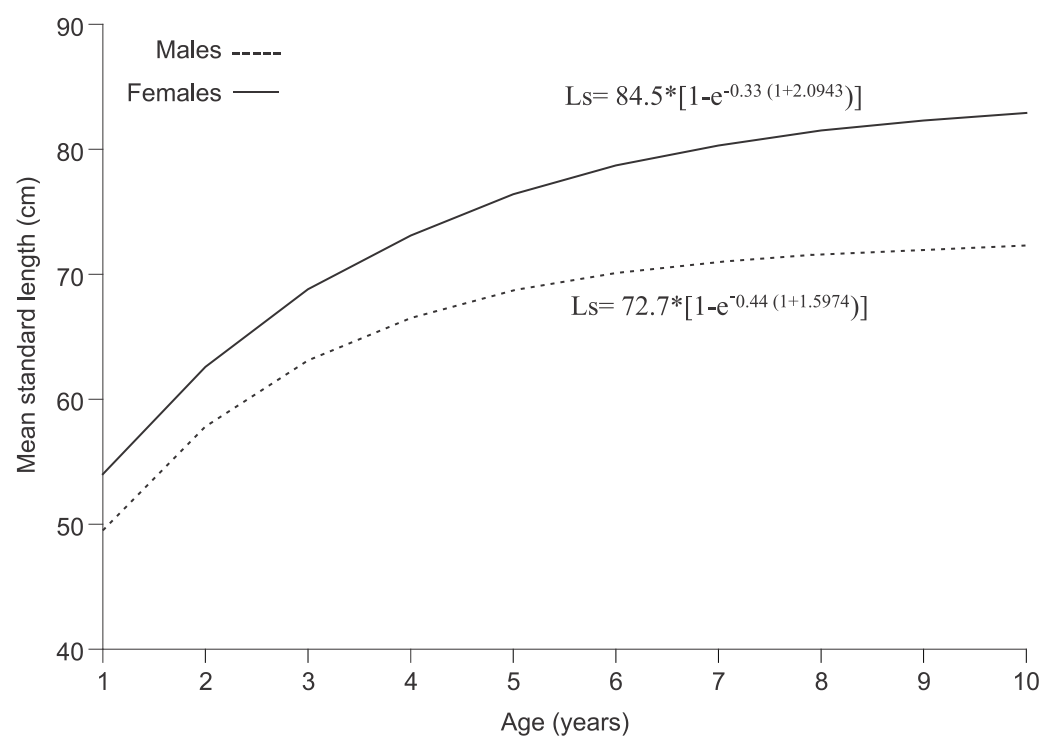

Fig. 3. Growth curves in length for males and females of Pseudoplatystoma reticulatum (Eigenmann \& Eigenmann, 1889) collected between January and December of 2007 in APM Manso Reservoir and Cuiabá River, state of Mato Grosso, Brazil). 


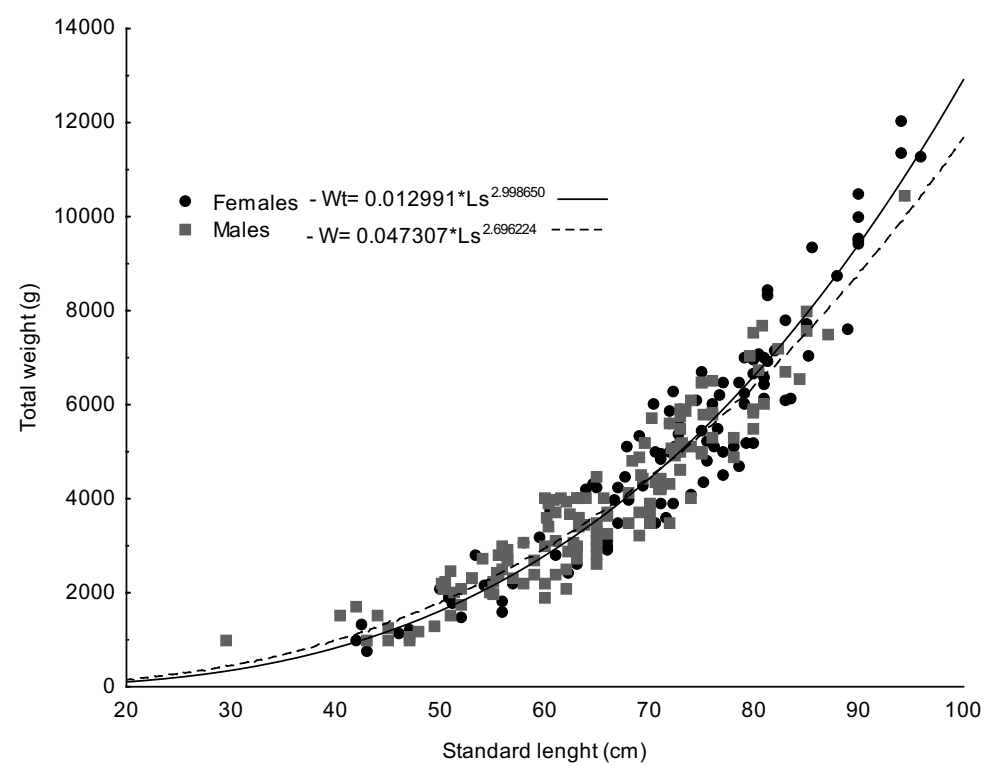

Fig. 4. Relationship between standard length $(\mathrm{cm})$ and total weight (g) for males and females of Pseudoplatystoma reticulatum (Eigenmann \& Eigenmann, 1889) collected between January and December of 2007 in the APM Manso Reservoir and the Cuiabá River, state of Mato Grosso, Brazil.

Beamish \& McFarlane, 1983; Cyterski \& Spangler, 1996; Ambrósio \& HayAshi, 1997; JePSEN et al., 1999; AmBrósio et al., 2003). This is especially true in regions where climate is less variable, which leads to weak apposition marks (AmBrósıo \& HAYASHI, 1997; AmBrósio et al., 2003). In addition, the process of estimating age incorporates biases associated with the non-formation of rings as fish grow, and these biases can lead to under- or overestimated ages (CAMPANA, 2001), both reflecting in the quality of the von Bertalanffy equation parameters. Another common error, according to this author, is related to the subjectivity in the estimates of age or the accuracy (interpretation of the numbers of rings) and precision (number of fish studied). This subjectivity arises during samplings (collection of fish), and may increase with preparation of material and interpretation of the growth marks (readings).

Formation of only one growth ring along a year is common in tropical regions (REINA et al., 1995; Ambrósio \& HaYAshi, 1997). However, to determine the timing and factor influencing the formation of growth rings in Neotropical fish is still a challenge. The formation of those rings in fish of the Neotropical region has been usually associated with spawning (BARBIERI, 1989; CAstro, 1998; BARBieri et al., 2000; Feitosa et al., 2004), especially in the studied region where annual mean temperature ranges from $21.4^{\circ} \mathrm{C}$ to $27.4^{\circ} \mathrm{C}$ (GIRARD et al., 2003).

AmBrósio et al. (2003) affirm that the most important mechanism affecting the growth rings' formation in fish from tropical regions is the reproductive process. During this process, several species may present suspension or reduction in feeding, and the growth of individuals decreases.

However, other aspects may be related to reproduction, such as maturation, migration, spawning, and parental care, exogenous factors frequently related to the formation of rings in calcified structures of tropical fish (Dudley, 1974; FAGAde, 1974; BARBIERI \& Barbieri, 1983; SAntos \& Barbieri, 1991). In the case of $P$. reticulatum, we observed that its reproduction in the region starts in November extending until March, period

Tab. I. Number of individuals analyzed $(\mathrm{N})$, mean standard length $(\mathrm{Ls} ; \mathrm{cm})$ and the coefficient of variation $(\mathrm{CV})$ of the mean standard length observed for each ring, for Pseudoplatystoma reticulatum (Eigenmann \& Eigenmann, 1889) collected between January and December of 2007 in APM Manso Reservoir and Cuiabá River, state of Mato Grosso, Brazil.

\begin{tabular}{|c|c|c|c|c|c|c|}
\hline \multirow[t]{2}{*}{ Rings } & \multicolumn{3}{|c|}{ Males } & \multicolumn{3}{|c|}{ Females } \\
\hline & $\mathrm{N}$ & Ls & $\mathrm{CV}$ & $\mathrm{N}$ & Ls & $\mathrm{CV}$ \\
\hline 1 & 6 & 46.03 & 9.50 & 8 & 49.51 & 5.19 \\
\hline 2 & 21 & 55.94 & 16.11 & 12 & 65.27 & 13.65 \\
\hline 3 & 31 & 64.89 & 12.34 & 23 & 71.87 & 12.20 \\
\hline 4 & 42 & 66.20 & 13.68 & 20 & 72.61 & 8.23 \\
\hline 5 & 28 & 67.53 & 12.68 & 23 & 76.30 & 10.59 \\
\hline 6 & 15 & 73.69 & 13.16 & 10 & 79.28 & 10.74 \\
\hline 7 & 3 & 66.10 & 9.52 & 5 & 83.80 & 9.51 \\
\hline 8 & & & & 3 & 92.60 & 4.50 \\
\hline
\end{tabular}


when the monthly means of the marginal increment are lower; therefore the growth rings seem to be related to the reproduction of the species.

Females of $P$. reticulatum presented higher growth rate than males and achieved longer length and weight, following the general pattern registered for fish (Wootton, 1998). The values of the parameter k estimated in this study were high ( 0.44 and 0.33 for males and females respectively). High values of $\mathrm{k}$ were also found for Salminus brasiliensis (Cuvier, 1817) in the upper Paraná River floodplain (0.28 for males and 0.26 for females) (Feitosa et al., 2004), and Corumbá Reservoir (0.77 for males and 0.52 for females) (DEI Tos et al. 2009). Despite being a Characiformes species, Salminus brasiliensis also migrates long distances like the Siluriformes $P$. reticulatum, and both species are classified as having the periodic strategy (WINEMILLER, 1989). These species maximize fecundity and are well suited to determine spatiotemporal variability.

Few studies have been conducted to estimate growth of fish in Neotropical region. Thus, this study represents the first to determine the age and growth parameter in Cuiabá River. The consistency of the readings was high, with coefficient of variation of the length, for each growth ring, lower than $17 \%$ for both sexes. The formation of the growth rings occurred in December, probably related to the reproduction of the species in the region, which extends from November to March. At last, the asymptotic length was within the range found in the literature.

Acknowledgements. The authors thank Núcleo de Pesquisas em Limnologia, Ictiologia e Aquicultura (Nupélia) for the logistic support during samplings and analyses of biological material. FURNAS Centrais Elétricas funded the study. LCG is researcher of $\mathrm{CNPq}$ (Productivity Scholarship).

\section{REFERENCES}

Albuquerque, S. P.; Campos, F. L. R. \& Catella, A. C. 2003. Sistema de controle da pesca de Mato Grosso do Sul SCPESCA/MS 9 - 2002. Corumbá, EMBRAPA, CPAP Boletim de Pesquisa 47. $57 \mathrm{p}$.

Ambrósio, A. M.; Gomes, L. C. \& Agostinho A. A. 2003. Age and growth of Hypophthalmus edentatus (Spix), (Siluriformes, Hypophthalmidae) in the Itaipu Reservoir, Paraná, Brazil. Revista Brasileira Zoologia 20(2):183-190.

Ambrósio, A. M. \& HaYASHI, C. 1997. Idade e crescimento de Steindachnerina insculpta (Fernández-Yepes, 1948), (Characiformes, Curimatidae) da planície de inundação do alto Rio Paraná, Brasil. Revista Brasileira de Biologia 57(4):687698.

BARBIERI, G. 1989. Dinâmica da reprodução e crescimento de Hoplias malabaricus (Bloch, 1794) (Osteichthyes, Erythrinidae) da represa do Monjolinho, São Carlos/SP. Revista Brasileira de Zoologia 6(2):225-233.

Barbieri, G. \& Barbieri, M. C. 1983. Growth and first sexual maturation size of Gymnotus carapo (Linnaeus, 1758) in the Lobo reservoir (state of São Paulo, Brazil) (Pisces, Gymnotidae). Revista Hydrobiologia Tropical 16(2):195201.

Barbieri, G.; Salles, F. A. \& Cestarolff, M. A. 2000. Análise populacional do curimbatá, Prochilodus lineatus, do rio Mogi Guaçu, Pirassununga/SP (Characiformes, Prochilodontidae). Boletim do Instituto de Pesca 26(2):17-25.
Beamish, R. J. \& McFarlane, G. A. 1983. The forgotten requirement for age validation in fisheries biology. Transactions of the American Fisheries Society 112(6):735-743.

CAmpana, S. E. 2001. Accuracy, precision and quality control in age determination, including a review of the use and abuse of age validation methods. Journal of Fish Biology 59:197-242.

Casselman, J. M. 1983. Age and growth assessment of fish from their calcified structures - techniques and tools. - U. S Department of Commerce, NOAA (National Oceanic and Atmospheric Administration). Technical Report NMFS (National Marine Fisheries Service) 8:1-6.

Castro, A. C. L. 1998. Idade e crescimento de Plagioscion squamosissimus (Heckel, 1840) (Acanthopterygii, Scianidae) do reservatório de Barra Bonita-SP, através da estrutura dos otólitos. Acta Scientiarum 20(2):179-184.

Cyterski, M. J. \& Spangler, G. R. 1996. A tool for age determination. North American Journal of Fisheries Management 16:403412.

Dei Tos, C.; Gomes, L. C. \& Agostinho, A. A. 2009. Age, growth, mortality and yield per recruit of the dourado Salminus brasiliensis, Corumbá Reservoir, Goiás State, Brazil. Neotropical Ichthyology 7(2):223-230.

Dudley, R. G. 1974. Growth of Tilapia of the Kafue Floodplain, Zambia: predicted effects of Kafue Gorge Dam. Transactions of the American Fisheries Society 103(2):81-91.

FAGADE, S. O. 1974. Age determination in Tilapia melanotheron (Rüppel) in the Lagos Lagoon, Lagos, Nigeria, with a discussion of the environmental and physiological basis of growth markings in the tropics. In: Bagenal, T. B. ed. The ageing of fish. Surrey, Unwin Brothers. p. 71-77.

Feitosa, L. A.; Fernandes, R.; Gomes, L. C. \& Agostinho, A. A. 2004. Parâmetros populacionais e simulação do rendimento por recruta de Salminus brasiliensis (Cuvier, 1816) do alto rio Paraná. Acta Scientiarum 26(3):317-323.

Ferreira, B. P. \& Russ, G. R. 1994. Age validation and estimation of growth rate of the coral trout, Plectropomus leopardus, (Lacépede 1802) from Lizard Island, Northern Great Barrier Reef. Fishery Bulletin 92(1):46-57

Girard, P.; Silva, C. J. \& Abdo, M. 2003. River-groundwater interactions in the Brazilian Pantanal: the case of the Cuiabá River. Journal of Hydrology 283:57-66.

Jepsen, D. B.; Winemiller, K. O.; Taphorn, D. C. \& Olarte, D. R. 1999. Age structure and growth of peacock cichlids from rivers and reservoirs of Venezuela. Journal of Fish Biology 55(2):433450.

Lai, H. L.; Galucci, V. F.; Gunderson, D. R. \& Donnelly, R. F. 1996. Age determination in fisheries: Methods and applications to stock assessment. In: Galucci, V. F.; Salla, S. B.; Gustafson, D. J. \& RотнлсніLD, B. J. eds. Stock assessment Quantitative methods and apllications for small-scale fisheries. Florida, Lewis Publishers. p. 82-170.

LE Cren, E. D. 1951. The length-weight relationship and seasonal cycle in gonad weight and condition in the Perch (Perca fluviatilis). Journal of Animal Ecology 20(2):201-219.

Mateus, L. A. F.; Penha, J. M. F. \& Petrere JR, M. 2004. Fishing resources in the rio Cuiabá basin, Pantanal do Mato Grosso, Brazil. Neotropical Ichthyology 2(4):217-227.

Menon, M. D. 1953. The determination of age and growth of fishes of tropical and subtropical waters. Journal Bombay Natural History Society 51(3):623-635.

Nikolsky, G. V. 1969. Theory of fish population dynamics. Edinburg, Oliver and Boyd. 321p.

Oliveira, M. T.; Nachp, A. M.; Vechi Jr, K.; Santana-Porto, E. A. \& Duarte, J. A. 2005. Determinação do ciclo reprodutivo de peixes reofílico de interesse comercial da Sub-Bacia do Rio Cuiabá. Available at: <http://www.seb-ecologia.org.br/viiceb/ resumos/339a. pdf>. Accessed on: 30.11.2010.

Petrere JR, M. \& Agostinho, A. A. 1993. La pesca en el tramo brasileno del Rio Parana. Fao Informe de Pesca 490:52-72.

Reina, M. P.; Ramírez, H. \& Valderrama, B. M. 1995. Edad y crescimiento de Paulicea luetikeni (Steindachner, 1976) (Pisces: Pimelodidae) basado en la lectura de estructuras duras (espinha de aleta pectoral) em el alto rio Meta (Colombia). Boletim Científico do Instituto Nacional de Pesquisas da Amazônia 3:115-135. 
Resende, E. K; Pereira, R. A. C.; Almeida, V. L. L. \& Silva, A. G. 1996. Alimentação de peixes carnívoros da planície inundável do rio Miranda, Pantanal, Mato Grosso do Sul, Brasil. CPAP Boletim de Pesquisa 03. Corumbá, EMBRAPA. 36p.

SAntos, G. B. \& Barbieri, G. 1991. Idade e crescimento de Prochilodus marggravii (Walbaum, 1972) (Characiformes, Prochilodontidae) do rio São Francisco, Minas Gerais, Revista Ceres 38(215):5-16.

Silva, M. V. 1986. Mitos e verdades sobre a pesca no Pantanal Sulmato-grossense. Campo Grande, FIPLAN/MS. 146p.

Tavares, M. P. 1997. O surubim. In: Miranda, M. O. T. org. Surubim. Belo Horizonte, IBAMA (Coleção Meio Ambiente, Série Estudos Pesca, 19). p. 9-25.
Vazzoler, A. E. A. M. 1981. Manual de métodos para estudos biológicos de população de peixes: reprodução e crescimento. Brasília, CNPq Programa Nacional de Zoologia. $106 \mathrm{p}$.

WALFORD, L. A. 1946. A new method of describing the growth of animals. Biology Bulletin 90(2):141-147.

Winemiller, K. O. 1989. Patterns of variation in life history among South American fishes in seasonal environments. Oecologia 81:225-241.

Wootton, R. J. 1998. Ecology of teleosts fishes. London, Chapman and Hall. 404p.

Recebido em 9 de fevereiro de 2011. Aceito em 29 de dezembro de 2011. ISSN 0073-4721

Artigo disponível em: www.scielo.br/isz

Impresso e distribuído em 2012. 